\title{
Screening Triploid Hybrids of 'Lakeland' Limequat for Resistance to Citrus Canker
}

\author{
Z. Viloria, Assistant Professor, La Universidad Del Zulia, Departamento Botanica, Maracaibo, Edo. Zulia, Republica \\ Bolivariana de Venezuela 4005ZU; D. L. Drouillard, Senior Biological Scientist, J. H. Graham, Professor, Univer- \\ sity of Florida, IFAS, Soil and Water Science Department, Citrus Research and Education Center, and J. W. Grosser, \\ Professor, University of Florida, IFAS, Horticultural Sciences, Citrus Research and Education Center, Lake Alfred \\ 33850
}

\begin{abstract}
Viloria, Z., Drouillard, D. L., Graham, J. H., and Grosser, J. W. 2004. Screening triploid hybrids of 'Lakeland' limequat for resistance to citrus canker. Plant Dis. 88:1056-1060.

Resistance of citrus genotypes to Xanthomonas axonopodis pv. citri, the cause of Asiatic citrus canker (ACC), was evaluated by injection infiltration of $10^{3}$ and $10^{4} \mathrm{CFU} / \mathrm{ml}$ through stomates on the abaxial surface of immature leaves. Citrus genotypes for screening comprised two autotetraploids and nine triploid hybrids of 'Lakeland' limequat (Citrus aurantifolia $\times$ Fortunella japonica) and their progenitors ('Lakeland' limequat, the autotetraploids 'Femminello' lemon (Citrus limon) and 'Giant Key' lime (C. aurantifolia), and the somatic hybrids 'Key' [also known as 'Mexican'] lime + 'Valencia' orange and 'Hamlin' orange + 'Femminello' lemon). 'Meiwa' kumquat (Fortunella crassifolia) and 'Pineapple' sweet orange (C. sinensis) were used as known resistant and susceptible standards, respectively. Lesion number per inoculation site and bacterial population per lesion were recorded 15 to 19 days after inoculation. The assay was performed four times during a spring-summer-fall period under greenhouse conditions. Canker lesions were consistently produced by stomatal inoculation with $10^{4}$ but not $10^{3} \mathrm{CFU} / \mathrm{ml}$. Susceptible and resistant genotypes were separated based on lesion number per inoculation site and bacterial population per lesion. Spearman's rank correlation analysis for lesion numbers on 15 genotypes common to all four assays showed significant correlations among the genotype rankings. Genotype rankings were also significantly correlated between the two bacterial population assays. Lesion number per inoculation site is sufficient for assessment of resistance of citrus genotypes to ACC without the necessity of conducting bacterial population assays. 'Lakeland' limequat is a promising seed parent for breeding acid citrus fruit that is resistant to ACC.
\end{abstract}

Xanthomonas axonopodis pv. citri strain A (syn. X. citri, X. campestris pv. citri) causes a serious leaf and fruit spotting disease of citrus known as Asiatic citrus canker (ACC). Strain A is virulent on all citrus species (11) and produces disease reactions that range from highly susceptible to resistant. 'Key' lime (Citrus aurantifolia (Christm.) Swingle), grapefruit $(C$. paradisi Macfad.), and certain sweet oranges (C. sinensis (L.) Osbeck) are among the most susceptible commercial varieties to ACC. Chemical control and cultural

Corresponding author: J. W. Grosser

E-mail: JWG@crec.ifas.ufl.edu

This research was supported by the Florida Agricultural Experiment Station and a grant from the Florida Citrus Production Research Advisory Council (Project 013-07P). This manuscript is approved for publication as Journal Series No. R09780.

Accepted for publication 6 May 2004.

Publication no. D-2004-0806-01R

(C) 2004 The American Phytopathological Society practices are part of integrated management systems applied in countries where ACC is endemic (14); nevertheless, Gottwald et al. (6) recently stated that it is probably less profitable to grow susceptible citrus varieties in tropical and subtropical climates in the presence of ACC, as a consequence of the high production costs linked with windbreaks and additional foliar sprays of copper bactericides.

More resistant cultivars are the best long-term solution for management of ACC. One approach for production of new varieties is introgression of canker resistance genes from resistant Citrus species or relatives into susceptible varieties. Field resistance to ACC occurs in calamondin (Citrus madurensis Lour.), kumquat (Fortunella margarita (Lour.) Swingle) $(17,18)$, and citrus relatives belonging to the genera Atalantia, Severinia, Feronia, and Microcitrus (18). Conventional approaches of citrus breeding for disease resistance in scion germ plasm are considered difficult because: (i) resistance mainly occurs in citrus relatives whose genetic makeup might interfere with the expres- sion of traits related to fruit quality and production, (ii) complications are imposed by long life cycles (21), and (iii) progenies from intergeneric crosses are generally small and/or perform poorly as a consequence of lethal recombination (1).

'Lakeland' limequat, an intergeneric hybrid between highly susceptible 'Key' lime and highly resistant kumquat (Fortunella japonica (Thunb.) Swingle), was identified as resistant to ACC after field evaluations of naturally infected budded trees and seedlings (18). Other hybrids of 'Mexican' lime, Nepali round hybrids (C. aurantifolia $\times C$. limon $)$ and Nepali oblong hybrids $(C$. aurantifolia $\times C$. medica), were reported to be ACC free and moderately resistant, respectively (17).

'Lakeland' limequat is a hybrid that bears Mexican lime acid-type fruit that is edible and also shows more cold hardiness than its female progenitor. The acid-citrus breeding program at the Citrus Research and Education Center (CREC), University of Florida, has generated 25 new 'Lakeland' limequat triploid hybrids through interploid crosses with allotetraploid somatic hybrids and autotetraploids during the 2000-2001 seasons (Z. Viloria and J. W. Grosser, unpublished). Currently, a large number of citrus allotetraploid somatic hybrids are available for use in scion breeding programs $(9,10)$. These allotetraploid parents can be used to increase the genetic diversity of new progenies with greater cold tolerance, seedlessness, ornamental tree value, and possibly greater resistance to ACC and other foliar diseases.

Screening of new citrus progenies for canker resistance requires an accurate, repeatable, and convenient inoculation technique that yields results in a reasonably short time (6). Screening for resistance under natural infection conditions has been carried out in countries where canker is widespread $(13,17,18,24)$; but at the initial stages, this approach cannot be applied in countries where ACC is under eradication and quarantines are imposed, such as in Florida (19). For greenhouse screening of citrus $X$. axonopodis pv. citri, several in- 
oculation techniques have been developed: wound inoculation of mesophyll tissue using pinprick $(5,7,17,20)$, leaf abrasion (3), injection-infiltration $(22,23)$, inoculation of wounded and nonwounded midveins of in vitro plants (15), and spray inoculation (13).

In field screening for ACC, Zubrzycki and Diamante de Zubrzycki (24) observed that resistance to natural infection was not always related to that induced by artificial inoculation. Cuticle develops rapidly during the leaf expansion process, which greatly influences water-soaking and bacterial infiltration via stomates (8), while bacterial growth in the intercellular spaces is determined by leaf mesophyll resistance $(22,23)$. Both external and internal mesophyll resistance increase dramatically with leaf expansion and maturation (8). Although most artificial inoculation methods bypass external factors contributing to leaf resistance, mesophyll resistance in citrus and citrus relatives is generally in accord with field resistance to ACC $(5,22)$. Gottwald and Graham (4) designed a stomatal inoculation apparatus that precisely injection-infiltrates bacterial inoculum into leaf mesophyll without injury. This inoculation method allowed for detailed assessment of bacterial population and lesion development at individual stomatal infection sites (4). Differences in bacterial growth and number of lesions among citrus scion and rootstock varieties varied in accordance with field resistance to ACC (8). Although highly precise, this laboratory-based inoculation method is impractical for large-scale screening of citrus germ plasm in the greenhouse or outdoor nursery.

The present research was undertaken to develop a more practical protocol for assessment of canker resistance by modification of the previous stomatal inoculation method. Here a handheld needleless syringe was used to injection-infiltrate a low density of bacteria to screen triploid hybrids of 'Lakeland' limequat and their progenitors under greenhouse conditions. The accuracy and reproducibility of this stomatal inoculation technique for evaluation of resistance was assessed by comparing the rankings of citrus genotypes based on lesion number and bacterial populations in the mesophyll in repeated assays.

\section{MATERIALS AND METHODS}

Four screening assays were performed in May, July, August, and November 2002 on the same set of plant material under quarantine at the Florida Department of Agriculture and Consumer ServicesDivision of Plant Industry (DPI) in Gainesville, FL.

Plant material. Nine replicate plants of 1-year-old triploid hybrids of 'Lakeland' limequat were selected along with the 'Lakeland' limequat seed parent and the following pollen parents: the auto- tetraploids 'Femminello' lemon and 'Giant Key' lime and two allotetraploid somatic hybrids 'Key' lime + 'Valencia' orange and 'Hamlin' orange + 'Femminello' lemon (Table 1). 'Hamlin' orange + 'Femminello' lemon was utilized as a seed parent as well. Two morphologically distinct 'Lakeland' limequat autotetraploid plants regenerated from a somatic fusion experiment were also tested (Z. Viloria and J. W. Grosser, unpublished).

'Meiwa' kumquat (Fortunella crassifolia Swingle) and 'Pineapple' sweet orange were included in the evaluation as ACC resistant and susceptible standards, respectively. Plants were maintained in $10 \times 10 \times$ $35 \mathrm{~cm}$ plastic pots containing Metro Mix 500 (The Scotts Co., Marysville, OH). Mineral nutrition was provided periodically with Essential Minor Elements (Agricultural Insecticides, Inc., Palmetto, FL) and Osmocote (Scotts). Lateral shoots were removed periodically to maintain a single, dominant shoot. Shoots were cut back to produce a single new shoot of comparable phenology for the different cultivars. Three to 4 weeks after cut back, there were sufficient immature leaves of the requisite expansion stage for inoculation. After each assay, trees were cut back to induce new growth flushes as needed for repetition of the experiment.

Inoculum and inoculation technique. The primary source of inoculum was cultures of $X$. axonopodis pv. citri A strain X02-007 from Broward County, FL, growing on nutrient agar (Difco Laboratories, Detroit, MI). The virulence of this isolate was representative of A strains from south Florida and elsewhere. For inoculation, cells in late log phase were harvested from nutrient broth medium (Difco) after growth for $24 \mathrm{~h}$ at 28 to $29^{\circ} \mathrm{C}$. After centrifugation of the cell suspension, the bacterial pellet was resuspended in $0.075 \mathrm{M}$ phosphate buffer ( $\mathrm{pH} 7.0)$ and the cell concentration adjusted to $10^{3}$ and $10^{4} \mathrm{CFU} / \mathrm{ml}$ using a spectrophotometer at $620 \mathrm{~nm}$. Bacterial concentration was confirmed by counting colonies on nutrient agar plates seeded with appropriate dilutions of the bacterial suspension.

Young, expanding leaves at 75 to $100 \%$ of full expansion were inoculated using a tuberculin syringe $(1 \mathrm{cc})$ with no needle. Inoculum was slowly infiltrated by pressing the needleless syringe tip against the abaxial leaf surface and placing a finger on

Table 1. Triploid progenies of 'Lakeland' limequat genotypes used in this study

\begin{tabular}{llc}
\hline \multicolumn{2}{c}{ Progenitors } & \\
\hline Seed & \multicolumn{1}{c}{ Pollen } & Progenies \\
\hline 'Lakeland' limequat & 'Key' lime + 'Valencia' orange & B1 \\
'Lakeland' limequat & 'Hamlin' orange + 'Femminello' lemon & B2 \\
'Lakeland' limequat & 'Giant Key' lime & B3 \\
'Lakeland' limequat & Autotetraploid 'Femminello' & B4 (1-3)*z \\
'Hamlin' orange + 'Femminello' lemon & 'Lakeland' limequat & GB $(1-3)^{*}$ \\
\hline z $*$ indicates three different hybrids from B4 and GB were tested.
\end{tabular}

the opposite side of the leaf for counterpressure to induce a zone of water-soaking in tissue $2 \mathrm{~mm}$ beyond the diameter of the syringe opening. The infiltrated area of the leaf was approximately $6 \mathrm{~mm}$ in diameter and contained an estimated $2 \mu \mathrm{l}$ of bacterial suspension. After the wiping of excess suspension from the leaf surface, the inoculated shoots were covered with plastic bags for 2 to 3 days to maintain high humidity conducive for bacterial growth in the leaves. Three injection infiltrations per inoculum level were performed on the leaf blade on each side of the midvein. At least three leaves were inoculated per plant, and a maximum of three plants were tested per genotype. Experiments were conducted in a greenhouse with diurnal temperatures of $27 / 23^{\circ} \mathrm{C}$ (day/night) and an ambient photoperiod. Inoculated plants were rotated on the greenhouse bench twice a week.

Disease assessment. Number of lesions per inoculation site and bacterial population per lesion were recorded approximately 2 weeks after inoculation. Lesions were counted at each inoculation site on leaves using a $\times 10$ magnifying hand glass. Inoculation sites for sampling of bacterial population were chosen according to the mean number of lesions per site for each plant genotype. Four inoculation sites (two per plant) were excised from each genotype with a cork borer and ground individually in $2 \mathrm{ml}$ of phosphate buffer $(\mathrm{pH}$ 7.0). The tissue suspension was serially diluted $\left(10^{-2}\right.$ to $\left.10^{-5}\right)$ and spread on replicate plates containing KCB agar, a semiselective medium for xanthomonads (7). Three to 4 days after incubation, colonies were enumerated as the mean $\mathrm{CFU} / \mathrm{ml}$ from replicate samples. The bacterial counts were log transformed to stabilize variance. Lesion number per inoculation site was recorded in each of four assays, and bacterial population per lesion was evaluated in the last two assays.

Data analysis. The experiment setup in the greenhouse was a completely randomized design. Analysis of variance was conducted according to a Mixed Model procedure for a nested experiment (SAS Proc Mixed Model, SAS Institute, Cary, NC). Significance of differences in lesions per inoculation site and bacterial population per lesion among citrus genotypes was determined by Waller-Duncan $k$-ratio procedure at the $0.05 \%$ confidence level. Significance of the correlations between as- 
says of rankings of citrus genotypes based on lesion number and bacterial population per lesion was assessed by the Spearman's rank order correlation coefficient $r_{s}(16)$.
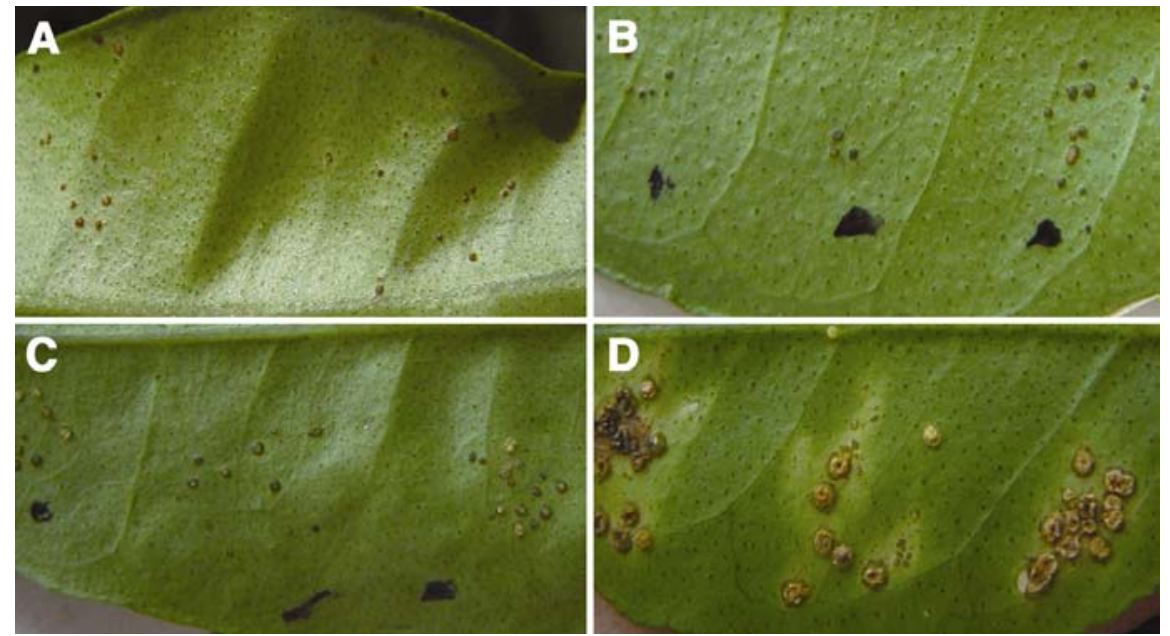

Fig. 1. Differences in phenotype of citrus canker lesions on the abaxial leaf surface of resistant (res), moderately resistant (mod), and susceptible (sus) citrus genotypes. A, 'Meiwa' kumquat (res) and B, 'Lakeland' limequat (res) lesions are small, orange to brown in color, and do not erupt through the leaf cuticle. C, 'Lakeland' limequat $\times$ 'Giant Key' lime (mod) lesions are small, brown, and slightly erumpent. D, 'Giant Key' lime (sus) lesions erupt through the leaf cuticle and continue to expand and eventually coalesce.

Table 2. Mean of lesion number per inoculation site after stomatal inoculation of Xanthomonas axonopodis pv. citri for 'Lakeland' limequat hybrids, their progenitors, and standard citrus genotypes for resistance ('Meiwa' kumquat) and susceptibility ('Pineapple' orange) to citrus canker in four assays ${ }^{\mathrm{x}}$

\begin{tabular}{lcccc}
\hline Genotype' $^{y}$ & May & July & August & November \\
\hline 'Giant Key' lime & $\ldots$ & $\ldots$ & $17.56 \mathrm{a}$ & $13.77 \mathrm{ab}$ \\
GB1 & $19.36 \mathrm{a}$ & $20.17 \mathrm{abcd}$ & $15.46 \mathrm{ab}$ & $23.36 \mathrm{a}$ \\
$\mathrm{B} 4-3$ & $17.33 \mathrm{ab}$ & $22.95 \mathrm{ab}$ & $10.08 \mathrm{abc}$ & $23.56 \mathrm{a}$ \\
$\mathrm{B} 3$ & $16.61 \mathrm{ab}$ & $19.40 \mathrm{bcde}$ & $13.10 \mathrm{ab}$ & $22.92 \mathrm{a}$ \\
GB2 & $16.37 \mathrm{ab}$ & $17.90 \mathrm{bcdef}$ & $12.00 \mathrm{ab}$ & $17.97 \mathrm{ab}$ \\
'Hamlin' + 'Femminello' & $15.72 \mathrm{abc}$ & $27.28 \mathrm{a}$ & $12.30 \mathrm{ab}$ & $14.63 \mathrm{ab}$ \\
Autotetraploid 'Femminello' & $13.97 \mathrm{abcd}$ & $24.71 \mathrm{ab}$ & $17.74 \mathrm{a}$ & $13.53 \mathrm{ab}$ \\
'Key' + 'Valencia' & $13.79 \mathrm{abcd}$ & $20.51 \mathrm{abcd}$ & $12.85 \mathrm{ab}$ & $16.05 \mathrm{ab}$ \\
'Pineapple' orange & $12.97 \mathrm{abcde}$ & $\ldots$ & $11.73 \mathrm{ab}$ & $16.25 \mathrm{ab}$ \\
GB3 & $12.41 \mathrm{bcde}$ & $22.63 \mathrm{ab}$ & $12.38 \mathrm{ab}$ & $11.99 \mathrm{ab}$ \\
B4-2 & $12.22 \mathrm{bcde}$ & $21.62 \mathrm{abc}$ & $11.96 \mathrm{ab}$ & $16.27 \mathrm{ab}$ \\
Autotetraploid 'Lakeland' & $11.11 \mathrm{bcde}$ & $8.09 \mathrm{gf}$ & $11.73 \mathrm{ab}$ & $15.58 \mathrm{ab}$ \\
B4-1 & $10.56 \mathrm{bcde}$ & $12.85 \mathrm{efg}$ & $10.48 \mathrm{abc}$ & $11.91 \mathrm{ab}$ \\
B1 & $9.00 \mathrm{cde}$ & $\ldots$ & $9.67 \mathrm{abc}$ & $\ldots$ \\
B2 & $8.52 \mathrm{de}$ & $14.45 \mathrm{cdefg}$ & $9.33 \mathrm{abc}$ & $14.25 \mathrm{ab}$ \\
'Lakeland' limequat & $7.78 \mathrm{de}$ & $11.17 \mathrm{fg}$ & $7.17 \mathrm{bc}$ & $8.722 \mathrm{~b}$ \\
*Autotetraploid 'Lakeland'z & $6.44 \mathrm{ef}$ & $10.96 \mathrm{fg}$ & $7.59 \mathrm{bc}$ & $8.18 \mathrm{~b}$ \\
'Meiwa' kumquat & $0.93 \mathrm{f}$ & $13.36 \mathrm{defg}$ & $3.11 \mathrm{c}$ & $8.72 \mathrm{~b}$ \\
\hline
\end{tabular}

${ }^{x}$ Different letters within each assay month indicate significant differences $(P<0.05)$ according to the Waller-Duncan $k$-ratio procedure.

${ }^{\text {y }}$ B1 = 'Lakeland' limequat $\times$ 'Key' lime + 'Valencia' orange; B2 = 'Lakeland' limequat $\times$ 'Hamlin' orange + 'Femminello' lemon; B3 = 'Lakeland' limequat $\times$ 'Giant Key' lime; B4 = 'Lakeland' limequat $\times 4 \times$ 'Femminello'; 1, 2, 3 indicate different hybrids; GB $=$ 'Hamlin' orange + 'Femminello' lemon $\times$ 'Lakeland' limequat; 1, 2, 3 indicate different hybrids.

$\mathrm{z} *$ indicates a morphologically different autotetraploid 'Lakeland' limequat.

Table 3. Spearman's rank order correlations, $r_{s}$, for rankings of citrus genotypes from four assays of lesion number/inoculation site after stomatal inoculation with Xanthomonas axonopodis pv. citri $^{\mathrm{z}}$

\begin{tabular}{lccc}
\hline & May & July & August \\
\hline July & 0.64643 & & \\
August & $P=0.0092$ & & \\
& 0.75000 & 0.60714 & \\
November & $P=0.0013$ & $P=0.0164$ & 0.52143 \\
& 0.86071 & 0.44286 & $P=0.0462$ \\
\hline
\end{tabular}

${ }^{\mathrm{z}} \mathrm{n}=15$ citrus genotypes common to all four assays (see Table 2 ).
Lesions were localized within the original water-soaked area at each inoculation site. In the first two assays, consistent differences among citrus genotypes in lesion number per inoculation site could not be discerned at the $10^{3} \mathrm{CFU} / \mathrm{ml}$ inoculum concentration. The coefficients of variation among genotypes were high, ranging between 57.08 and 75.12. Therefore, only the $10^{4} \mathrm{CFU} / \mathrm{ml}$ inoculum concentration was used in the subsequent two assays. Differences in lesion appearance between resistant and susceptible plants were noted. Lesions on resistant 'Meiwa' and 'Lakeland' limequat cultivars were small, orange to brown, and did not erupt through the leaf cuticle (Fig. 1A and B). Lesions were small, brown, and slightly erumpent on the two autotetraploid 'Lakeland' limequats (Fig. 1C) and the hybrids 'Lakeland' limequat $\times$ 'Giant Key' lime, 'Lakeland' limequat $\times$ ('Key' lime + 'Valencia' orange), and 'Lakeland' limequat $\times$ ('Hamlin' sweet orange + 'Femminello' lemon). Susceptible genotypes, e.g., 'Pineapple' sweet orange, 'Giant Key' lime, and 'Hamlin' sweet orange + 'Femminello' lemon, developed lesions that erupted through the leaf cuticle and continued to expand and eventually coalesce (Fig. 1D).

Lesion numbers were significantly different among genotypes for assays conducted in May, July, and August. Lesion numbers per inoculation site on susceptible 'Pineapple' sweet orange were consistently higher than on the resistant 'Meiwa' kumquat (Table 2). The hybrid from 'Giant Key' lime, two from 4x 'Femminello', and two from 'Hamlin' orange + 'Femminello' lemon as the seed parent had lesion numbers that ranked closer to the pollen progenitors. Other hybrids ('Lakeland' limequat $\times$ 'Key' lime + 'Valencia' orange and 'Lakeland' limequat $x$ 'Hamlin' orange + 'Femminello' lemon) developed fewer lesions than their pollen parents and ranked closer to 'Lakeland' limequat (diploid and autotetraploid genotypes) and 'Meiwa' kumquat. In the November assay, the difference among genotypes was marginally significant $(P=0.06)$. Nonetheless, the resistant 'Lakeland' limequat and 'Meiwa' ranked lowest in lesion number in this assay.

Spearman's rank correlation analysis for the lesion numbers on the 15 genotypes common to all four assays showed correlations among the genotype rankings (Table $3)$. The weakest relationships were observed between the ranking in November and that for July or August.

Significant differences in bacterial population per lesion were also observed among genotypes for the assays conducted in August and November. Highest bacterial population per lesion was recovered from susceptible 'Pineapple' sweet orange and the lowest from resistant 'Meiwa' kumquat in the August assay (Table 4). There was slight variation in the genotype rankings 
between the two population assays. Spearman's correlation coefficient for ranking of genotypes for the two bacterial assays was highly significant $\left(r_{s}=0.6082\right.$, $P<0.0001)$. The correlations for rankings of lesion number and bacterial population conducted in August $\left(r_{s}=0.59, P=\right.$ $0.0094)$ and November $\left(r_{s}=0.55, P=\right.$ 0.0217).

\section{DISCUSSION}

Stomatal inoculation of 15 closely related citrus genotypes with $X$. axonopodis pv. citri at $10^{4} \mathrm{CFU} / \mathrm{ml}$ produced differential responses of lesion number and bacterial population per lesion. Although $10^{3}$ $\mathrm{CFU} / \mathrm{ml}$ bacterial concentration was used previously to quantify mesophyll resistance (22), in the present study, the inoculation with $10^{4} \mathrm{CFU} / \mathrm{ml}$ gave most consistent numbers of lesions per inoculation site. The $10^{4}$ concentration is much lower than that used for screening by other inoculation methods $(2,5,15)$.

Rankings of citrus genotypes based on lesion numbers were mostly well correlated among four assays. Lower rank correlation coefficients between summer and fall assays may be related to differences in environmental conditions. Assays were performed in a greenhouse, but environmental variables such as shorter photoperiod and cooler temperatures in November probably influenced lesion development. These environmental conditions may have affected plant growth rate, expression of mesophyll resistance, and consequently, bacterial development in the leaf tissues. In November, lesions were not fully develper lesion were significant for the assays

oped by 15 days after inoculation, which necessitated extension of the disease expression period to 19 days. Yet, the ranking among genotypes in November was consistent with the assay conducted under conditions most favorable for bacterial growth in August.

Mesophyll resistance was expressed consistently in repeated assays despite variability in leaf type among the citrus genotypes. Shoots were cut back to produce expanding leaves of similar physiological and morphological development for inoculation to ensure, to the extent possible, uniformity in expression of leaf mesophyll resistance.

The concept of mesophyll resistance was supported by the relationship between symptom expression (lesion number) and bacterial population growth among susceptible and resistant genotypes. Genotype rankings of lesion number were closely related to bacterial population in the leaves; therefore, both variables were useful for assessment of mesophyll resistance. Similarly, Graham et al. (8), using a stomatal inoculation apparatus, correlated rankings of lesion numbers with bacterial population in a diverse group of citrus scions and rootstocks. In the previous study (8), correlation coefficients between bacterial population and lesion number were higher for resistant than susceptible varieties. Furthermore, bacterial growth slowed after 48 to $72 \mathrm{~h}$ in more resistant types but continued to increase in susceptible varieties. Koizumi (12) likewise reported slower lesion extension and lower populations in leaves of resistant plants compared with susceptible ones.

Table 4. Bacterial population per lesion after stomatal inoculation of Xanthomonas axonopodis pv. citri for 'Lakeland' limequat hybrids, their progenitors, and standard citrus genotypes for resistance ('Meiwa' kumquat) and susceptibility ('Pineapple' orange) to citrus canker in two assays ${ }^{\mathrm{x}}$

\begin{tabular}{lcc}
\hline Genotype $^{\mathbf{y}}$ & $\begin{array}{c}\text { August population } \\
\text { (Log CFU/lesion) }\end{array}$ & $\begin{array}{c}\text { November population } \\
\text { (Log CFU/lesion) }\end{array}$ \\
\hline 'Pineapple' orange & $5.23 \mathrm{a}$ & $4.55 \mathrm{abc}$ \\
'Giant Key' lime & $5.06 \mathrm{ab}$ & $4.15 \mathrm{bcd}$ \\
Autotetraploid 'Femminello' & $4.69 \mathrm{abc}$ & $4.34 \mathrm{abcd}$ \\
GB1 & $4.66 \mathrm{abc}$ & $4.46 \mathrm{abc}$ \\
B4-3 & $4.59 \mathrm{abcd}$ & $4.74 \mathrm{a}$ \\
'Hamlin' + 'Femminello' & $4.58 \mathrm{abcd}$ & $4.57 \mathrm{abc}$ \\
B4-1 & $4.54 \mathrm{abcd}$ & $4.61 \mathrm{ab}$ \\
GB2 & $4.44 \mathrm{abcd}$ & $4.56 \mathrm{abc}$ \\
B2 & $4.43 \mathrm{abcd}$ & $4.50 \mathrm{abc}$ \\
'Key' lime + 'Valencia' & $4.34 \mathrm{cbd}$ & $4.75 \mathrm{a}$ \\
B4-2 & $4.05 \mathrm{cde}$ & $3.93 \mathrm{de}$ \\
GB3 & $4.05 \mathrm{cde}$ & $4.07 \mathrm{cde}$ \\
B3 & $3.96 \mathrm{cde}$ & $4.34 \mathrm{abcd}$ \\
Autotetraploid 'Lakeland' limequat & $3.75 \mathrm{de}$ & $3.85 \mathrm{de}$ \\
B1 & $3.33 \mathrm{e}$ & $\ldots$ \\
* Autotetraploid 'Lakeland' limequat ${ }^{2}$ & $3.33 \mathrm{e}$ & $3.58 \mathrm{ef}$ \\
'Lakeland' limequat & $3.31 \mathrm{e}$ & $2.86 \mathrm{~g}$ \\
'Meiwa' kumquat & $2.38 \mathrm{f}$ & $3.19 \mathrm{fg}$ \\
\hline
\end{tabular}

${ }^{\mathrm{x}}$ Different letters within each assay month indicate significant differences $(P<0.05)$ according to the Waller-Duncan $k$-ratio procedure.

y $\mathrm{B} 1=$ 'Lakeland' limequat $\times$ 'Key' lime + 'Valencia' orange; B2 $=$ 'Lakeland' limequat $\times$ 'Hamlin' orange + 'Femminello' lemon; B3 = 'Lakeland' limequat $\times$ 'Giant Key' lime; B4 = 'Lakeland' limequat $\times 4 \times$ 'Femminello'; 1, 2, 3 indicate different hybrids; GB $=$ 'Hamlin' orange + 'Femminello' lemon $\times$ 'Lakeland' limequat; 1, 2, 3 indicate different hybrids.

$\mathrm{z} *$ indicates a morphologically different autotetraploid 'Lakeland' limequat.
Bacterial population assessment is a precise method to determine quantitative resistance, but the logistics of performing bacterial assays for germ plasm screening at a remote quarantine laboratory make it impractical. Lesion number is a reliable, quantitative, and convenient measure of resistance to ACC without further measurement of bacterial population.

'Lakeland' limequat was confirmed to be a promising seed parent for breeding acid citrus fruit that is resistant to ACC. 'Lakeland' limequat autotetraploids and the triploid hybrids, 'Lakeland' limequat $\times$ 'Key' lime + 'Valencia' orange and 'Lakeland' limequat $x$ 'Hamlin' orange + 'Femminello' lemon, also showed potentially useful levels of resistance. Overall, these results indicate that canker resistance from kumquat can be readily incorporated into acid-fruit hybrids by conventional breeding. Such an approach may also have potential for improvement of resistance of mandarin fruit varieties if the maternal (seed) parent carries the resistance genes. Hybrids from 'Lakeland' limequat as a pollen parent (GB1 and GB2) showed higher susceptibility than hybrids from the same used as the seed parent. Continued evaluation of the canker-resistant triploid hybrids for horticultural attributes could yield a lime-type fruit tree with acceptable resistance to replace traditional lime trees in yards of south Florida that are being destroyed as part of the canker eradication program (19).

\section{LITERATURE CITED}

1. Barrett, H. C. 1985. Hybridization of Citrus and related genera. Fruit Var. J. 39:11-16.

2. Dienelt, M. M., and Lawson, R. H. 1989. Histopathology of Xanthomonas campestris pv. citri from Florida and Mexico in woundinoculated detached leaves of Citrus aurantifolia: Transmission electron microscopy. Phytopathology 79:336-348.

3. Din Khan, I., and Hingorani, M. K. 1970. Strain studies in Xanthomonas citri (Hasse) Dowson. J. Hortic. Sci. 45:15-17.

4. Gottwald, T. R., and Graham, J. H. 1992. A device for precise and nondisruptive stomatal inoculation of leaf tissue with bacterial pathogens. Phytopathology 82:930-935.

5. Gottwald, T. R., Graham, J. H., Civerolo, E. L., Barrett, H. C., and Hearn, C. J. 1993. Differential host range reaction of citrus and citrus relatives to citrus canker and citrus bacterial spot determined by leaf mesophyll susceptibility. Plant Dis. 77:1004-1009.

6. Gottwald, T. R., Graham, J. H., and Schubert, T. S. 2002. Citrus canker: The pathogen and its impact. Published online. Plant Health Progress Doi:10.1094/PHP-2002-0812-01-RV.

7. Graham, J. H., Gottwald, T. R., and Fardelmann, D. 1990. Cultivar-specific interactions for strains of Xanthomonas campestris from Florida that cause citrus canker and citrus bacterial spot. Plant Dis. 74:753-756.

8. Graham, J. H., Gottwald, T. R., Riley, T. D., and Achor, D. 1992. Penetration through leaf stomata and growth of strains of Xanthomonas campestris in citrus cultivars varying in susceptibility to bacterial diseases. Phytopathology 82:1319-1325.

9. Grosser, J. W., Jiang, J., Mourao-Fo, F. A. A., Louzada, E. S., Baergen, K., Chandler, J. L., 
and Gmitter, F. G., Jr. 1998. Somatic hybridization, an integral component of citrus cultivar improvement: I. Scion improvement. Hortic. Sci. 33:1057-1059.

10. Grosser, J. W., Ollitrault, O., and OlivaresFuster, O. 2000. Somatic hybridization in citrus: An effective tool to facilitate variety improvement. In vitro Cell. Dev. Biol. 36:434449.

11. Koizumi, M. 1981. Resistance of citrus plants to bacterial canker disease: A review. Proc. Int. Soc. Citric. 1:402-405.

12. Koizumi, M. 1985. Citrus canker: The world situation. Pages 2-7 in: Symposium of Citrus Canker: An International Perspective. L. W. Timmer, ed. Citrus Research and Education Center, University of Florida, Lake Alfred.

13. Leite, R. P., Jr., and Mohan, S. K. 1984. Evaluation of citrus cultivars for resistance to canker caused by Xanthomonas campestris pv. citri (Hasse) Dye in the state of Parana, Brazil. Proc. Int. Soc. Citric. 1:35-38.

14. Leite, R. P., Jr., and Mohan, S. K. 1990. Inte- grated management of the citrus bacterial canker disease caused by Xanthomonas campestris pv. citri in the State of Paraná, Brazil. Crop Prot. 9:3-7.

15. López, M. M., and Navarro, L. 1981. A new in vitro inoculation method for citrus canker diagnosis. Proc. Int. Soc. Citric. 1:399-402.

16. Lyman Ott, R. 1993. An Introduction to Statistical Methods and Data Analysis. Duxbury Press, Belmont, CA.

17. Prasad, M. B. N. V., Singh, R., Rekha, A., and Chand, R. 1997. Evaluation of lemon cultivars and acid lime $\times$ lemon hybrids for resistance to Xanthomonas axonopodis pv. citri. Sci. Hortic. 71:267-272.

18. Reddy, M. R. S. 1997. Sources of resistance to bacterial canker in citrus. J. Mycol. Plant Pathol. 27:80-81.

19. Schubert, T. S., Rizvi, S. A., Sun, X. Gottwald, T. R., Graham, J. H., and Dixon, W. N. 2001. Meeting the challenge of eradicating citrus canker in Florida-Again. Plant Dis. 85:340-356.
20. Shiotani, H., Ozaki, K., and Tsuyumu, S. 2000. Pathogenic interactions between Xanthomonas axonopodis pv. citri and cultivars of pummelo (Citrus grandis). Phytopathology 90:13831389.

21. Soost, R. K., and Roose, M. 1996. Citrus. Pages 257-323 in: Fruit Breeding: Tree and Tropical Fruits, vol. 1. J. Janick and J. N Moore, eds. John Wiley \& Sons, New York.

22. Stall, R. E., Marco, G. M., and Canteros de Echenique, B. I. 1982. Importance of mesophyll in mature-leaf resistance to cancrosis of citrus. Phytopathology 72:1097-1100.

23. Stall, R. E., Miller, J. W., Marco, G. M., and de Echenique, B. I. C. 1980. Population dynamics of Xanthomonas citri causing cancrosis of citrus in Argentina. Proc. Fla. State Soc. 93:10-14.

24. Zubrzycki, H. M., and Diamante de Zubrzycki, A. 1981. Resistance to Xanthomonas campes tris pv. citri (Hasse) Dowson in oranges (Cit rus sinensis (L.) Osbeck). Proc. Int. Soc. Citric. 1:405-409. 